\title{
Hepatitis B virus infections in apparently healthy urban Nigerians: data from pre-vaccination tests
}

\author{
Moses P. Adoga ${ }^{1,2}$, Silas D. Gyar ${ }^{2}$, Simon Pechulano ${ }^{3}$, Obadiah D. Bashayi ${ }^{3}$, Samuel E. \\ Emiasegen ${ }^{4}$, Timothy Zungwe ${ }^{1}$, Odunayo $\mathrm{H}$. Iperepolu ${ }^{1}$, Chinwe Agupugo ${ }^{5}$, Simon M. Agwale ${ }^{1,6}$ \\ ${ }^{1}$ Virology Department, Innovative Biotech Ltd, No. 1, Abdu Abubakar Street, GRA, P.O.Box 30, Keffi, Nasarawa State, Nigeria \\ ${ }^{2}$ Microbiology Unit, Department of Biological Sciences, Faculty of Natural and Applied Sciences, Nasarawa State University, \\ Keffi, Nigeria \\ ${ }^{3}$ Department of Clinical Services, Innovative Biotech Ltd, No. 1, Abdu Abubakar Street, GRA, P.O.Box 30, Keffi, Nasarawa \\ State, Nigeria \\ ${ }^{4}$ Department of Clinical Pathology, General Hospital Akwanga, Nasarawa State, Nigeria \\ ${ }^{5}$ Department of Statistics, Innovative Biotech Ltd, No. 1, Abdu Abubakar Street, GRA, P.O.Box 30, Keffi, Nasarawa State, \\ Nigeria \\ ${ }^{6}$ Virology Department Innovative Biotech USA Inc, Frederick Innovative Technology Center, 4539 Metropolitan Ct, Frederick MD \\ 21704, USA
}

\begin{abstract}
Background: In spite of the availability of an effective vaccine since 1982 against hepatitis B, infection with hepatitis B virus (HBV), which is 50 to 100 times more infectious than HIV, still persists in most parts of the world with Nigeria being described as an endemic zone. We therefore set out to establish the prevalence of this infection and evaluate its relationship with age and gender in urban Nigerians.

Methodology: During pre-vaccination tests, blood samples were collected by finger-prick and venepuncture from 1,891 subjects aged $\leq 60$ years, between 2008 and 2009 after having obtained informed consent and ethical clearance. Smart Check HBsAg (Globalemed, Cape Town, South Africa) and ShantestTM-HBsAg Elisa (Shantha Biotechnics Ltd, Hyderabad, India) were used for initial and confirmatory tests respectively.

Results: Of the 1,891 participants, 957 (50.6\%) were males and 934 (49.4\%) were females. Overall 114 (6.0\%) were positive, of whom 71 (7.4\%) were males and $43(4.6 \%)$ females. Those aged 21-30 years had the highest infection rate, and males were more likely to be infected with the virus than females $(\mathrm{P}>0.05)$.

Conclusions: Such a high prevalence of a vaccine-preventable infection questions the effectiveness of the Nigerian vaccination strategies. The Nigerian government hepatitis B vaccination programme, which hitherto is limited to the National Childhood Immunisation Programme, should include the adult population.
\end{abstract}

Key Words: Hepatitis B Virus; prevalence; vaccination; Nigeria

J Infect Dev Ctries 2010; 4(6):397-400.

(Received 18 October 2009 - Accepted 31 January 2010)

Copyright () 2010 Adoga et al. This is an open-access article distributed under the Creative Commons Attribution License, which permits unrestricted use, distribution, and reproduction in any medium, provided the original work is properly cited.

\section{Introduction}

Hepatitis B virus (HBV) infection is a major public health problem worldwide. HBV is 50 to 100 times more infectious than HIV, and it is an important cause of liver diseases such that chronic infection with $\mathrm{HBV}$ is a common cause of death associated with liver failure, cirrhosis, and liver cancer [1-3]. The endemicity of HBV in Nigeria has been variously described [4-6].

Globally, more than two billion people alive today have been infected with $\mathrm{HBV}$ at some time in their lives. Of these, about 350 million have chronic (lifelong) infections and become carriers of the virus
[1,3]. These chronically infected persons are at high risk of death from liver cirrhosis and hepatocellular carcinoma, diseases that kill about one million persons each year. Every year there are over four million acute clinical cases of HBV [3].

The risk of death from HBV-related liver cancer or cirrhosis is approximately $25 \%$ for persons who acquire chronic infection at childhood $[1,3]$. Moreover, $8 \%$ to $10 \%$ of people in the general population in the developing world become chronically infected and most acquire infection with HBV at childhood $[3,7]$. 
Although hepatitis $\mathrm{B}$ vaccination is highly effective in preventing infection with $\mathrm{HBV}$ and consequent acute and chronic liver disease [1], this infection is still a major problem in Nigeria as reported by various scientists [6,8-10]. The Nigerian government $\mathrm{HBV}$ vaccination programme that is designed only for children (excluding adults) might be a major contributing factor.

The need for periodic monitoring of the trend of infection in the general population as a necessary tool for effective intervention initiatives cannot be overemphasized. Therefore, using a representative sample size, we set out to determine the prevalence of this infection and evaluate its association with age and gender in apparently healthy urban Nigerians.

\section{Materials and methods}

Study area and population

The study area was comprised of the Nigerian Federal Capital Territory (FCT), Abuja, and part of Mararaba town at the boundary between Nasarawa State and the FCT. Abuja and Nasarawa State are located in the north-central zone of Nigeria. A total of 1,891 residents of the area, most of whom came from different parts of Nigeria, participated in our vaccination exercises and were considered for the study.

\section{Ethical consideration}

Informed consent of each participant was obtained prior to testing. Ethical approval was also obtained from our Research Ethics Institutional Review Board.

\section{Inclusion and Exclusion Criteria}

All subjects who gave informed consent were included in the study. Subjects who had once been vaccinated with the required three doses of the vaccine and those who declined to offer consent were excluded from the study.

\section{Specimen Collection and Assay}

In the course of our routine HBV vaccination exercises mostly targeting the adult population, finger-prick whole blood samples were collected for pre-vaccination tests from 1,891 participants aged $\leq$ 60 years, between January 2008 and January 2009, after having obtained informed consent and clearance from our research ethics institutional review board. On-the-spot testing for HBsAg was conducted using Smart Check HBsAg (Globalemed, Cape Town,
South Africa) according to the manufacturer's instructions. Next $3 \mathrm{ml}$ of blood was then aseptically collected by venepuncture from each reactive participant and conveyed in ice packs to our facility, where their respective plasma in EDTA containers were separated into cryovials. Confirmatory tests were then performed with Shantest ${ }^{\mathrm{TM}}-\mathrm{HBsAg}$ ELISA (Shantha Biotechnics Ltd, Hyderabad India) according to the manufacturer's instructions.

\section{Statistical Analysis}

Data were subjected to statistical analysis using statistical software StatView version 4.5 (Abacus Concepts Inc, Piscataway, USA). Pearson chi-square was calculated at $95 \%$ confidence interval. $\mathrm{P}$ value $\leq$ 0.05 was considered significant.

\section{Results}

A total of 1,891 subjects participated. Of these, $957(50.6 \%)$ were males and $934(49.4 \%)$ were females. Overall $114(6.0 \%)$ were positive for HBV. Of the 957 male and 934 female participants, 71 (7.4 $\%)$ and $43(4.6 \%)$ were infected respectively. Those aged 21-30 years had the highest infection rate, and males were more likely to be infected with the virus than females $(\mathrm{P}>0.05)$. Table 1 shows the overall and the age-sex matched prevalence rates.

\section{Discussion}

The discovery of such a high HBV prevalence of $6.0 \%$ in this study, among an urban population which supposedly should have a low prevalence rateunlike rural populations where most practices such as poor adherence to vaccination schedules, relatively low vaccination coverage, sharing of drinking cups, and relatively frequent unprotected sex favour transmission-underscores the endemicity of hepatitis B in Nigeria.

The finding is consistent with earlier reports. For instance, prevalence rates of $8.9 \%$ and $10.3 \%$ have been reported among women of child-bearing age in Lagos, Nigeria and in the general population of Uganda in a national sero-survey respectively $[10,11]$. However, inconsistent findings with ours of much higher seroprevalence rates of $26.0 \%, 15.1 \%$, $13.2 \%$ and $12.6 \%$ have been reported in Nigeria $[9,12,14,15]$. The smaller sample sizes used by those researchers might explain the wide gaps that exist between their findings and ours.

Similarly, high seroprevalence rates, for instance, $17.1 \%, 23.0 \%, 9.2 \%$ and $26.5 \%$ have been reported 
among the Nigerian high-risk populations of commercial sex workers, prison inmates and HIV/AIDS patients $[3,5,17,18]$. All these reports no
This study was done in an urban population that should have a lower prevalence rate than rural populations based on previous findings [11, 21].

Table 1. Age and sex distribution of Hepatitis B Virus infections among Nigerians

\begin{tabular}{|l|l|l|l|l|l|l|}
\hline Age (Yrs) & № Tested & \multicolumn{2}{|c|}{ Sex } & \multicolumn{2}{c|}{ № Positive } & № / \% Positive \\
\hline & & Male & Female & Male (\%) & Female (\%) & \\
\hline$\leq 10$ & 409 & 216 & 193 & $8(3.7)$ & $4(2.1)$ & $12(2.9)$ \\
\hline $11-20$ & 647 & 293 & 354 & $25(8.5)$ & $17(4.8)$ & $42(6.5)$ \\
\hline $21-30$ & 401 & 186 & 215 & $24(12.9)$ & $13(6.0)$ & $37(9.2)$ \\
\hline $31-40$ & 264 & 138 & 126 & $10(7.2)$ & $7(5.6)$ & $17(6.4)$ \\
\hline $41-50$ & 138 & 101 & 37 & $4(4.0)$ & $2(5.4)$ & $6(4.3)$ \\
\hline $51-60$ & 32 & 23 & 9 & $0(0.0)$ & $0(0.0)$ & $0(0.0)$ \\
\hline Total & 1891 & 957 & 934 & $71(7.4)^{*}$ & $43(4.6)^{*}$ & $114(6.0)$ \\
\hline *P Value $=0.98$, Male vs Female
\end{tabular}

doubt attest to the endemicity of hepatitis $\mathrm{B}$ in Nigeria.

However, comparatively lower seroprevalence rates of $3.2 \%$ and $4.98 \%$ have also been reported in Nigeria $[19,20]$. This study revealed that the males with the prevalence rate of $7.4 \%$ were more likely to be infected with the virus than females who had $4.6 \%$ infection rate. Although this did not reach statistical significance $(P>0.05)$, implying that the difference might be due to chance, our finding is in accord with previous studies that reported higher infection rates among males than females [11-13,16]. No concrete explanations can be given for the higher vulnerability of males to the infection than females.

When we compared prevalence rates across age groups, there was a relatively high infection rates across all the age brackets, though those aged 21-30 were more likely to be infected followed by those aged 11-20 years, with the difference not reaching statistical significance $(\mathrm{P}>0.05)$. This implies that the difference might be a product of chance. However, previous findings have found significant association with age [11,19]. Given the sexual transmission of HBV, the high sexual activity of individuals within these age brackets might explain this.

Considering the age groups most infected in this study, one can speculate that the major transmission mode in this population is sexual intercourse; however, this hypothesis needs further evaluation. ;An incidence study could provide better understanding, since this study evaluated only the prevalence and it is possible that some of the infected subjects acquired infection at childhood either vertically (mother-to-child) or by other transmission routes.
Hence a much higher seroprevalence rate should be expected in a Nigerian general population study that will include rural populations. We therefore recommend that a Nigerian national survey like the Ugandan study [11] be conducted, as this will be a useful aid in understanding the situation in the general population, and in the planning of intervention initiatives, including a vaccination policy. Such a survey could be included in the Nigerian HIV/AIDS sentinel survey.

Such a high prevalence in an urban population questions the effectiveness of the Nigerian HBV vaccination programme. The role of vaccination in overcoming hepatitis B cannot be overemphasised. A notable example is a study in China that found reduced prevalence of $\mathrm{HBsAg}$ to be strongly associated with vaccination among all age groups [22]. We recommend that the Nigerian government HBV vaccination programme should be extended to the adult population and not just limited to the national childhood immunisation programme.

\section{Acknowledgements}

We are indebted to Innovative Biotech Ltd for sponsoring this work.

\section{References}

1. Weinbaum CM, Williams I, Mast EE, Wang SA, Finelli L, Wasley A, Neitzel SM, Ward JW (2008) Recommendations for Identification and Public Health Management of Persons with Chronic Hepatitis B Virus Infection. MMWR 57: 1-20.

2. Souza KP, Luz JA, Teles SA, Carneiro MA, Oliveira LA, Gomes AS, Dias MA, Gomes SA, Yoshida CF, Martins RM (2003) Hepatitis B and C in the Hemodialysis Unit of Tocantins, Brazil: Serological and Molecular Profiles. Menorias do Instituto Oswaldo Cruz 98: 599-603. 
3. World Health Organisation (2009) Hepatitis B Fact sheet $\mathrm{N}^{\mathrm{O}} 204$. Accessed 10 June 2009. Available: http://www.who.int/csr/disease/hepatitis.

4. Forbi JC, Onyemauwa N, Gyar SD, Oyeleye AO, Entonu P, Agwale SM (2008) High prevalence of hepatitis B virus among female sex workers in Nigeria. Rev Inst Trop Sao Paulo; 50: 219-221.

5. Onyekwere CA, Anomneze EE, Wali SS (2002) Prevalence of serological markers of chronic hepatitis B virus infection in diabetes in the Lagos University Teaching Hospital, Lagos. Niger Postgrad Med J 9: 129-133.

6. Adoga MP, Banwat EB, Forbi JC, Nimzing L, Pam CR, Gyar SD, Agabi YA, Agwale SM (2009) Human Immunodeficiency Virus, Hepatitis B Virus and Hepatitis C Virus: Sero-prevalence, Co-infection and Risk Factors among Prison inmates in Nasarawa State, Nigeria. J Infect Dev Ctries 3: 539-547.

7. EASL International Consensus Conference on Hepatitis B, 13-14 September, 2002, Geneva, Switzerland (2003) Consensus Statement. Journal of Hepatology 38: 533-540.

8. Otegbayo JA, Fasola FA, Abja A (2003). Prevalence of Hepatitis B surface and e antigens, risk factors for viral acquisition and serum transaminase among blood donors in Ibadan, Nigeria. Trop Gastroenterol 24: 196-197.

9. Halim NKD, Offor E, Ajayi OI (1999) Epidemiology study of the sero-prevalence of hepatitis $\mathrm{B}$ surface antigen (HBsAg) and HIV-1 in blood donors. Niger J Clin Pract 2: 42-45.

10. Aganga-Williams OM, Akanmu AS, Akinsete I (1999) Prevalence of hepatitis B surface antigen among women of child-bearing age in Lagos State. African Journal of Reproductive Health 3: 45-50.

11. Bwogi J, Braka F, Makumbi I, Mishra V, Bakamutumaho B, Nanyunja M, Opio A, Downing R, Biryahwaho B, Lewis RF (2009) Hepatitis B infection is highly endemic in Uganda: findings from a National serosurvey. African Health Sciences 9: 98-108.

12. Jombo GI, Egah DZ, Banwat EB (2005). Hepatitis B virus infection in a rural settlement of northern Nigeria. Niger $\mathbf{J}$ Med 14: 425-428.

13. Okpalugo CE, Oguntibeju OO (2008) Prevalence of human immunodeficiency virus and hepatitis $B$ virus in preoperative patients: Potential risk of transmission to health professionals. Pak J Biol Sci 11: 298-301.

14. Egah DZ, Banwat EB, Audu ES, Iya D, Mandong BM, Anele AA, Gomwalk NE (2007) Hepatitis B surface antigen, hepatitis $\mathrm{C}$ and HIV antibodies in a low-risk blood donor group, Nigeria. East Mediterr Health J 13: 961-966.

15. Fasola FA, Kotila TR, Akinyemi JO (2008) Trends in transfusion-transmitted viral infections from 2001 to 2006 in Ibadan, Nigeria. Intervirology 51: 427-431.

16. Otegbayo JA, Taiwo BO, Akingbola TS, Odaibo GN, Adedapo KS, Penugonda S, Adewole IF, Olaleye DO, Murphy R, Kanki P (2008) Prevalence of hepatitis B and C seropositivity in a Nigerian cohort of HIV-infected patients. Ann Hepatol 7: 152-156.

17. Mustapha SK, Jibrin YB (2004) The prevalence of hepatitis $B$ surface antigenaemia in patients with human immunodeficiency virus (HIV) infection in Gombe, Nigeria. Ann Afr Med 3: 10-12.

18. Lesi OA, Kehinde MO, Oguh DN, Amira CO (2007). Hepatitis B and C virus infection in Nigerian patients with HIV/AIDS. Niger Postgrad Med J 14: 129-133.

19. Odusanya OO, Meurice FP, Hoet B (2007) Nigerian medical students are at risk for hepatitis B infection. Trans R Soc Trop Med Hyg 101: 465-468.

20. Ejele OA, Ojule AC (2004) The prevalence of hepatitis B surface antigen ( $\mathrm{HBsAg}$ ) among prospective blood donors and patients in Port Harcourt, Nigeria. Niger J Med 13: 336338.

21. Magoni M, Ekra KD, Aka LN, Sita KS, Kanga K (2009) Effectiveness of hepatitis-B vaccination in Ivory Coast: the case of the Grand Bassam health district. Ann Trop Med Parasitol 103: 519-527.

22. Liang X, Bi S, Yang W, Wang L, Cui G, Cui F, Zhang Y, Liu J, Gong X, Chen Y, Wang F, Zheng H, Wang F, Guo J, Jia Z, Ma J, Wang H, Luo H, Li L, Jin S, Hadler SC, Wang Y (2009) Epidemiological serosurvey of hepatitis B in China: Declining HBV Prevalence due to hepatitis B vaccination. Vaccine 27: 6550-6557.

\section{Corresponding author}

Simon M. Agwale

Virology Department

Innovative Biotech USA Inc

Frederick Innovative Technology Center

4539 Metropolitan Ct,

Frederick MD 21704, US

sagwale@innovativebiotechng.com, adogamoses@yahoo.com

Conflict of interests: No conflict of interests is declared. 